\title{
Spontaneous bacterial peritonitis caused by Streptococcus bovis: case report and review of the literature
}

Authors

Rosmari Hörner ${ }^{1}$

Adenilde Salla ${ }^{1}$

Loiva Otonelli de

Oliveira $^{1}$

Nara Lucia Frasson Dal

Forno $^{1}$

Roselene Alves Righi ${ }^{1}$

Vanessa Oliveira

Domingues $^{1}$

Fabiane Rigatti

Letícia Eichstaedt Mayer ${ }^{1}$

${ }^{1}$ Universidade Federal de Santa Maria, Santa Maria, RS, Brazil.

Submitted on: 08/6/2009 Approved on: 12/22/2009

\section{Correspondence to:} Profa. Dra. Rosmari Hörner

Universidade Federal de Santa Maria (UFSM) Avenida Roraima, 1000 C, Centro de Ciências da Saúde, Prédio 26, 20 andar/sala 1216, Departamento de Análises Clínicas e Toxicológicas, Cidade Universitária,

Camobi Santa Maria - RS

- Brazil

Phone: +55-55-32208464 Fax: +55-55-32208018

E-mail:

rosmari.ufsm@gmail.com

We declare no conflict of interest.

\begin{abstract}
Spontaneous bacterial peritonitis (SBP) is a frequent and severe complication that occurs in patient with cirrhosis and ascites. It occurs in $10 \%$ to $30 \%$ of patients admitted to hospital. The organisms that cause SBP are predominantly enteric. Escherichia coli is the most frequent recovered pathogen, and Gram-positive bacteria, mainly Staphylococcus spp., are being considered an emerging causative agent of SBP. Streptococcus bovis that may be found as part of the commensal bowel flora in about $10 \%$ of healthy adults constitute an uncommon cause of peritonitis that was first reported in 1994. We describe the first case of SBP at the University Hospital of Santa Maria (HUSM) caused by S. bovis, resistant to the antibiotics erythromycin and clindamycin (inducible clindamycin resistance detected by disk diffusion test using the D-zone test).
\end{abstract}

Keywords: peritonitis, Streptococcus bovis, cirrhosis, ascites.

[Braz J Infect Dis 2010;14(3):294-296]@Elsevier Editora Ltda.

Bacterial infections are a frequent and severe complication of liver cirrhosis. The spontaneous bacterial peritonitis (SBP) is a common complication of cirrhotic patients with ascites. All cirrhotic patients with ascites can develop SBP. ${ }^{1}$ The prevalence of SBP in cirrhotic patients with ascites admitted to a hospital ranges between $10 \%$ and $30 \% .^{2,3}$ A vast majority of such infections are due to gastrointestinal Gram-negative bacteria, mainly Enterobacteriaceae. However, these data refer mainly to community-acquired infections. The etiologies of nosocomial infections have undergone changes, and Gram-positive bacteria have emerged as the most common cause of infection among hospitalized patients. ${ }^{4}$ Staphylococcus aureus is actually recognized as an important pathogen in cirrhotic patients. ${ }^{5}$ Different species of Streptococcus have been isolated from ascitic fluid. Although, Streptococcus bovis is a rare cause of SPB and has only been reported in a few cases ${ }^{6}$ first related in $1994 .^{7}$ we report a case of spontaneous bacterial peritonitis due to this microorganism and review the previous reports.

\section{CASE REPORT}

A 75-year-old man with cirrhosis due to alcohol abuse, diagnosed 3 years before admission, was admitted with fever, fine tremor, abdominal pain, abdominal distention, and diarrhea. On presentation, his temperature was $37.8^{\circ} \mathrm{C}$. Laboratory tests revealed an $\mathrm{Hb}$ of $8.8 \mathrm{~g} / \mathrm{dL}$; hematocrit 29\%, white blood cell (WBC) count of $6,400 / \mathrm{mm}^{3}$ with $18 \%$ neutrophils; AST $44 \mathrm{UI} / \mathrm{L}$, ALT $17 \mathrm{UI} / \mathrm{L}$, alkaline phosphatase $54 \mathrm{UI} / \mathrm{L}$, gamma-glutamyl transferase (GGT) $11 \mathrm{UI} / \mathrm{L}$, total bilirubin 2.65 $\mathrm{mg} / \mathrm{dL}$, direct bilirubin $1.30 \mathrm{mg} / \mathrm{dL}, \mathrm{C}$-reactive protein $13.27 \mathrm{mg} / \mathrm{dL}$, urea $106.6 \mathrm{mg} / \mathrm{dL}$, creatinine $2.6 \mathrm{mg} / \mathrm{dL}$. Ceftriaxone therapy was started empirically for treatment of intra-abdominal infection. The patient died one day after hospitalization. Streptococcus bovis was subsequently isolated of ascitic fluid.

\section{PAST MEDICAL HISTORY}

The patient was being monitored at HUSM since 2005 when he presented mild chronic gastritis, grade 2, no atrophic, with search of Helicobacter pylori positive; antibodies anti$\mathrm{HBc}$ non-reagent. In 2007, he was admitted to this hospital, with diffuse abdominal pain, and abdominal distention; through upper endoscopy was diagnosed esophageal varices and portal hypertension. The patient was submitted to paracentesis; the culture of ascitic fluid was negative. Empirical antibiotic therapy was initiated 
Table 1. Summary of clinical information for reported cases of spontaneous bacterial peritonitis due to S. bovis infection

\begin{tabular}{|c|c|c|c|}
\hline Case reports (number of patients) & Age (yr) (sex) & Clinical presentation & Outcome \\
\hline Lossos I et al., 1994 (1) & $25(\mathrm{M})$ & Fever, fatigue, jaundice & Recovery \\
\hline Ackerman et al., 1995 (1) & $69(\mathrm{M})$ & Fever, GI bleeding & Recovery \\
\hline Gloria et al., 1996 (2) & $52(\mathrm{M}), 58(\mathrm{M})$ & $\begin{array}{l}\text { Fever (2), jaundice, change in } \\
\text { mental status, abdominal pain }\end{array}$ & Death \\
\hline Macedo et al., 1997 (1) & $57(\mathrm{M})$ & Fever, abdominal pain & Recovery \\
\hline Shad and Schindler, 1999 (1) & $70(\mathrm{~F})$ & Change in mental status & Recovery \\
\hline Genuth, 2000 (1) & $64(\mathrm{M})$ & $\begin{array}{l}\text { Abdominal pain, abdominal } \\
\text { distention }\end{array}$ & Recovery \\
\hline Eledrisi et al., 2000 (1) & $46(\mathrm{M})$ & Abdominal pain, GI bleeding & Recovery \\
\hline Vilaichone et al. 2001 (7) & $\begin{array}{l}54(\mathrm{~F}), 58(\mathrm{~F}), 58(\mathrm{M}), \\
62(\mathrm{~F}), 65(\mathrm{~F}), 69(\mathrm{~F}), \\
63(\mathrm{~F})\end{array}$ & $\begin{array}{l}\text { Fever ( } 7 \text { ), GI bleeding (2) } \\
\text { abdominal pain (2), } \\
\text { abdominal distention (4), } \\
\text { change in mental status (3), } \\
\text { jaundice }\end{array}$ & Recovery \\
\hline Hörner et al., 2009 (1) & $75(\mathrm{M})$ & $\begin{array}{l}\text { Fever, abdominal pain, } \\
\text { abdominal distention, diarrhea }\end{array}$ & Death \\
\hline
\end{tabular}

immediately with ceftriaxone. The suspected diagnosis was hepatocellular carcinoma.

Table 1 presents a summary of the sixteen patients with spontaneous bacterial peritonitis due to $S$. bovis, reported in the literature, and important clinical information.

\section{DISCUSSION}

To our knowledge, there are only fifteen cases of spontaneous peritonitis due to S. bovis, reported in English and Portuguese literature: we describe the sixteenth case. ${ }^{6-13}$ Most patients with spontaneous bacterial peritonitis presents fever, abdominal pain, abdominal distention, and jaundice. Spontaneous bacterial peritonitis due to $S$. bovis infections usually occurs in elderly patients with equal frequency in male and female $(8: 7){ }^{6}$

S. bovis is a rare cause of spontaneous bacterial peritonitis in patients with cirrhosis. ${ }^{13} \mathrm{~S}$. bovis is a group $\mathrm{D}$ nonenterococcal streptococcus, frequently found as part of the comensal bowel flora in humans and animals. ${ }^{14-16}$ The association between invasive $S$. bovis infections and endocarditis or intestinal pathologies is well established. S. bovis bacteremia has long been known to be associated with colon cancer. ${ }^{6,15}$ However, different Streptococcus bovis biotypes, now renamed as Streptococcus equinus, Streptococcus gallolyticus [Streptococcus bovis I], Streptococcus pasteurianus [Streptococcus bovis II/2], and Streptococcus infantarius [Streptococcus bovis II/1] are associated with different diseases. ${ }^{14,17}$ Streptococcus bovis I, which ferment the mannitol, is found to have a stronger association with bacteremia and infective endocarditis in patients with intestinal pathologies than biotype II/1. On the other hand, Streptococcus bovis biotype II is associated with chronic liver diseases. Thus, it is important for the clinical microbiology laboratory to identify the biotype of S. bovis isolated from sterile body sites. ${ }^{17}$ The biochemical identification (MicroScan - DADE - Siemens) of $S$. bovis isolated from the patient's case report indicated that it refers to biotype S. bovis II/2 (Streptococcus pasteurianus). S. bovis type 2 is the most common type of $S$. bovis that causes spontaneous bacterial peritonitis and was found in others reported cases. ${ }^{6,7,13}$

Clinical isolates of Streptococcus bovis are usually sensitive to penicillin. Intravenous penicillin is the antimicrobial agent of first choice. ${ }^{6,16}$ Reports on the susceptibility of S. bovis are scarce. ${ }^{18}$ Macrolides and related drugs have been suggested as alternative for treatment of streptococcal infections when the patient is allergic to penicillin. However, high rates of resistance to erythromycin have been identified in S. bovis isolates from blood cultures in Taiwan. ${ }^{16}$ Two major mechanisms account for erythromycin resistance in many Gram-positive bacteria: target site modification and active efflux. ${ }^{19}$ Target site modification, generally known as macrolide-lincosamide-streptogramin B (MLS) resistance, is mediated by Erm methylases, which methylate $23 \mathrm{~S}$ rRNA and induce ribosome modification. Expression of MLS resistance in streptococci can be either constitutive (cMLS) or inducible (iMLS).

Antimicrobial susceptibility testing of the isolate was carried out by automation (Micro-Scan - DADE - Siemens): the antibiotics penicillin, ampicillin, clindamycin, and levofloxacin were sensitive. By disk diffusion method, performed 
with agar Mueller-Hinton containing 5\% sheep blood, in accordance with the guidelines established by the Clinical and Laboratory Standards Institute, ${ }^{20}$ the strain was resistant to erythromycin.

Flattening of the zone of inhibition adjacent to the erythromycin disk referred to as a D-zone was visible, indicating an inducible type of macrolides-lincosamidesstreptogramins (iMLS) resistance. Resistance to both erythromycin and clindamycin indicated $\mathrm{MLS}_{\mathrm{B}}$ crossresistance.

In the present study, Streptococcus bovis showed the iMLS phenotype, visualized to as D-zone: $\mathrm{D}$-test positive, that is, resistance to antibiotics erythromycin and clindamycin evidenced by the method of induction.

Therefore, the aim of this study was to report our experience with the isolation of Streptococcus bovis in ascitic fluid of a patient with liver cirrhosis due to alcohol abuse.

Intravenous penicillin is still the antimicrobial agent of first choice for S. bovis spontaneous bacterial peritonitis. However, cefotaxime also can be effectively used in these kinds of infections. ${ }^{11}$ The overall mortality was $25 \%$ (4/16 patients).

The isolation of $S$. bovis indicates to the clinician a poor prognosis for his patient who should have a more detailed monitoring. Thus, a detailed investigation of the entire large intestine is necessary in patients in whom S. bovis was isolated, even in the absence of intestinal symptoms.

\section{REFERENCES}

1. Rimola A, Tsao G G, Navasa M et al. Diagnosis and prophylaxis of spontaneous bacterial peritonitis: a consensus document. J Hepatol 2000; 32:142-53.

2. Garcia-Tsao G. Spontaneous bacterial peritonitis. Gastroenterol Clin N Am 1992; 21:257-75.

3. Pinzello G, Somonetti R, Camma C et al. Spontaneous bacterial peritonitis: an update. Gastroenterol Int 1993; 6:54-60.

4. Singh N, Paterson D L, Chang FY et al. Methicillin-resistant Staphylococcus aureus: the other emerging resistant gram-positive coccus among liver transplant recipients. Clin Infect Dis 2000; 30:322-7.

5. Chang FY, Singh N, Gayowski T et al. Staphylococcus aureus in patients with cirrhosis prospective assesment of association with infection. Infect Control Hosp Epidemiol 1998; 19:328-32.
6. Vilaichone RK, Mahachai V, Kullavanijaya P et al. Spontaneous bacterial peritonitis caused by Streptococcus bovis: case series and review of the literature. Am J Gastroenterol 2002; 7(6):1476-79.

7. Lossos IS, Schwaber MJ, Levin T et al. Spontaneous peritonitis caused by Streptococcus bovis. J Clin Gastroenterol 1994; 19:346.

8. Ackerman Z, Eliakim R, Stalnikowicz R et al. Spontaneous peritonitis caused by Streptococcus bovis: search for colonic neoplasia. J Clin Gastroenterol 1995; 21:263.

9. Gloria H, Ducla-Soares J, Sorejo F et al. Streptococcus bovis spontaneous bacterial peritonitis in patient with alcoholic cirrhosis. Eur J Gastroenterol Hepatol 1996; 8:823-4.

10. Macedo G, Queiroz H, Ribeiro T. Liver biopsy as a cause of Streptococcus bovis peritonitis. J Clin Gastroenterol 1997; 24:292-3.

11. Shad JA, Schindler WR. Spontaneous peritonitis due Streptococcus bovis. Am J Gastroenterol 1999; 94:2327(letter).

12. Genuth L. Re: Shad and Schindler's report on spontaneous peritonitis due to Streptococcus bovis. Am J Gastroenterol 2000; 95:840-1.

13. Eledrisi MS, Zuckerman MJ, Ho H. Spontaneous Bacterial Peritonitis caused by Streptococcus bovis. Am J Gastroenterol 2000; 95:1110-1(letter).

14. Wong SSY, Woo PCY, Ho PL, Wang TKF. Continuous Ambulatory Peritoneal Dialysis-Related Peritonitis Caused by Streptococcus bovis. Eur J Clin Microbiol Infect Dis 2003; 22:424-6.

15. Waisberg J, Matheus CO, Pimenta J. Infectious endocarditis from Streptococcus bovis associated with colonic carcinoma: case report and literature review. Arq Gastroenterol 2002; 39: 177-180.

16. Teng LJ, Hsueh PR, Ho SW, Luh KT. High Prevalence of Inducible Erythromycin Resistance among Streptococcus bovis Isolates in Taiwan. Antimicrob Agents Chemother, 2001; 3362-5.

17. Koneman EW, Allen SD, Janda WM et al. Diagnóstico Microbiológico - Texto e Atlas Colorido. São Paulo: Guanabara Koogan, 2008.

18. Avial IR, Avial CR, Culebras E et al. In vitro activity of telithromycin against Viridans Group Streptococci and Streptococcus bovis from blood: antimicrobial susceptibility patters in different groups of species. Antimicrob Agents Chemother 2005; 49(2):820-3.

19. Leclercq R, Huet C, Picherot $M$ et al. Genetic basis of antibiotic resistance in clinical isolates of Streptococcus gallolyticus (Streptococcus bovis). Antimicrob Agents Chemother 2005; 49(4):646-8.

20. Clinical and Laboratory Standards Institute, 2008. Performance standards for antimicrobial susceptibility testing, Eighteenth Informational Supplement, document M100-S18. Wayne, PA, USA: CLSI. 